\title{
Darko ŠARAC
}

\section{Vpliv vojn na nastanek in razvoj naselij: primer Ljubljane}

Čeprav so v strokovni literaturi o nastanku Ljubljane navedena že mnoga zgodovinsko dokazana dejstva, še vedno obstajajo številna pomembna vprašanja o prvotnem nastanku ljubljanske naselbine na sedanji lokacij, ki niso popolnoma raziskana. Med temi vprašanji so prav gotovo tudi vzroki, ki niso dovolj natančno obravnavani ne samo v zgodovinski, ampak tudi v obstoječi literaturi o urbanizmu in arhitekturi Ljubljane, predvsem o tem, kako so vojne in vojne dejavnosti vplivale na izbiro lokacije in razvoj tega mesta. Odgovore smo iskali s pomočjo poglobljene in sistematične raziskave strateških ali vojnih vplivov na območju Evrope, Sredozemlja in Bližnjega vzhoda.
Razvoj Ljubljane smo podrobneje preučili v časovnem okviru od prazgodovine do trojnega naselbinskega jedra Stare Ljubljane (Stari trg, Novi trg in Mestni trg) v srednjem veku. Spoznanja, ki smo jih pridobili s to raziskavo, so nas približala odgovoru na zastavljeno vprašanje, ali je prvo naselbinsko jedro Ljubljane (Stari trg) nastalo le kot naključna naselbina ali pa je bila ta lokacija izbrana zaradi vpliva vojn na tem območju.

Ključne besede: vplivi, vojne, prostori, naselbine, lokacije, urbanizem 


\section{Uvod}

Kot potrjujejo študije (na primer Bleiken, 1976; Bogdanović, 1976; Gruden, 1992; Košir, 1993, in Reisp, 1998), so velike geopolitične spremembe v različnih prostorih (mednje štejemo tudi preseljevanje ljudstev) vedno nastajale kot posledica vojn. John Keegan (2005: 7 in 8) je o vojni zapisal:

[V]ojna je ena od bistvenih dejavnosti človeka v vseh časih in vseh kulturah in je o njej treba neprestano razmišljati. Vse umetnosti, filozofije, mitologije, teologije in znanosti se ukvarjajo z vojno. Vse humanistične in naravne znanosti, ki so nastale v procesu drobljenja (specializacije) človeških znanj, se ukvarjajo z vojno in človeškim nasiljem. Prav tako bo težko ovreči trditev, da so pomembne tehnološke iznajdbe nastale prvotno v vojaške in šele sekundarno v civilne namene $/ . .$.

Ker nova vojaška struktura po navadi vedno prevzema dominantno vlogo $\mathrm{v}$ osvojenem prostoru in ga $\mathrm{v}$ svojem interesu vsebinsko spreminja, so vojne zmeraj prinašale nove vrednote, ki so potem posledično vplivale na tamkajšnjo arhitekturo in urbanizem vsega prostora. Vojne niso povzročile le propada poraženih držav v teritorialnem smislu, ampak tudi propad nji- hovih tradicionalnih kulturnih dosežkov in prebivalstva. Prav to ugotavljamo tudi na primeru rimske Emone - antičnega mesta na območju Ljubljane -, ki je imela pomembno vlogo pri urbanističnem razvoju Ljubljane v srednjem veku (slika 1; za pregled glej Tomažič, 1937; Stele, 1939, in Korošec, 1991).

Vojne so procesi, ki nenehno potekajo v svetovni zgodovini ter ves čas pomembno vplivajo na različne oblike človeškega življenja in njegovega razvoja. $\mathrm{V}$ zadnjih tri tisoč petsto letih naj bi bilo po svetu okoli 14.500 večjih in manjših vojn. Zato te s svojo dejavnostjo spadajo med izpostavljene dejavnike, ki v različnih časovnih obdobjih različno vplivajo na razvoj urbane in arhitekturne podobe mest (glej Tomažič,1938; Mumford, 1969, ali Košir, 1993). Cilj bojevanja je bil zmeraj enak. Usmerjen je bil k fizičnemu uničevanju ali zasužnjevanju nasprotnika in osvojitvi njegovega ozemlja, to je osvojitvi njegovih naselbin oziroma v poznejši zgodovini mest. Najbolj raziskano je področje vpliva, ki ga je vojskovanje imelo na razvoj naselbin $v$ srednjem veku, ko so se te zaradi nenehnih medsebojnih spopadov vladarjev utrdile $s$ fortifikacijskimi sistemi. $V$ ta namen so na evropskih dvorih že takrat imeli usposobljene vojaške strokovnjake za izgradnjo utrdb, z drugimi besedami, strokovnjake za strateško urbano preventivo. Prav dejstvo, da so vojaški

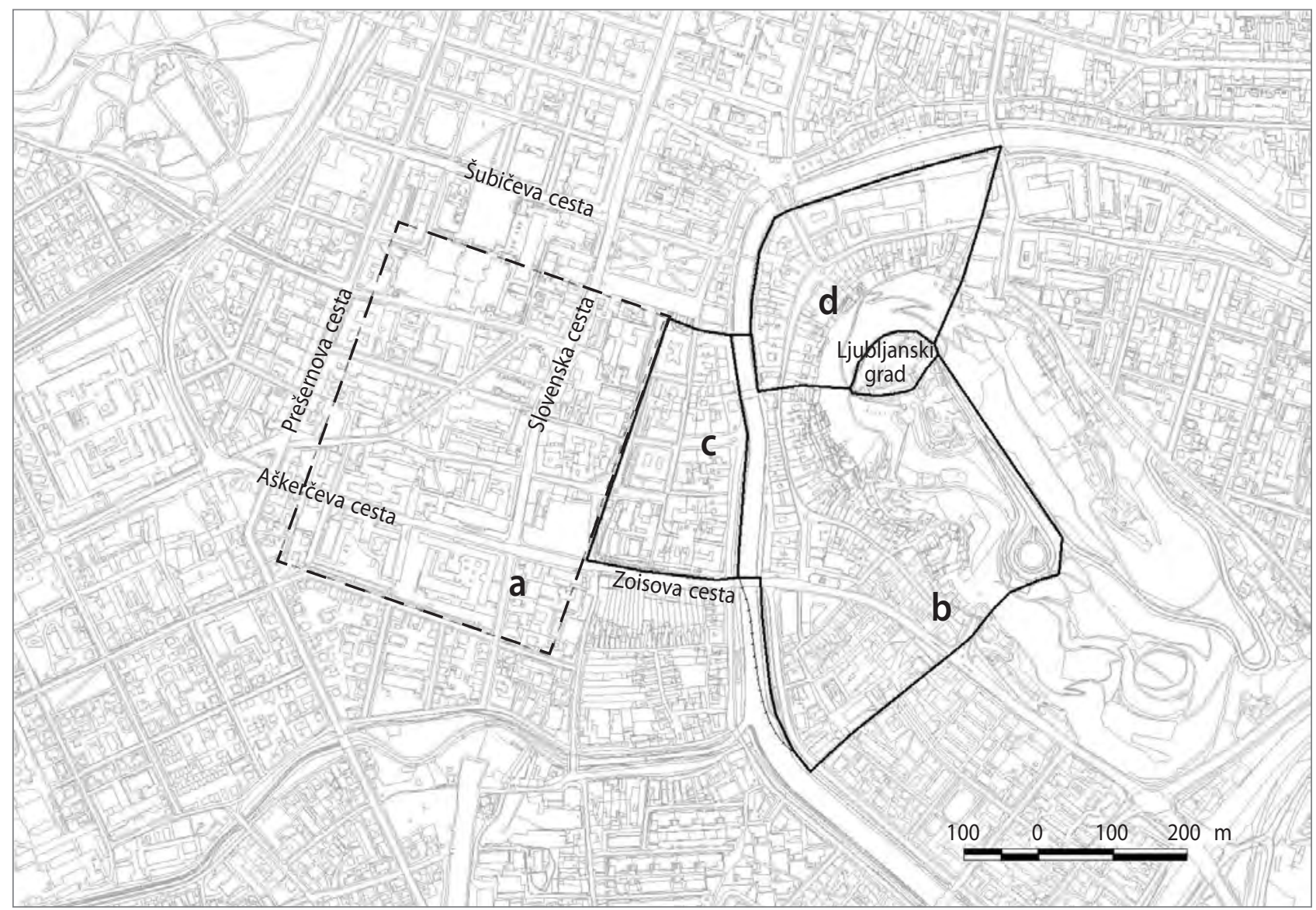

Slika 1: Zemljevid ožjega središča današnje Ljubljane: (a) lega rimske Emone; (b) prvo naselbinsko jedro Ljubljane - Stari trg; (c) drugo naselbinsko jedro Ljubljane - Novi trg; (d) tretje naselbinsko jedro Ljubljane - Mestni trg (vir: Šarac, 2013) 
strokovnjaki Angielini, Pieroni in Stier med letoma 1586 in 1676 oblikovali strateške urbanistične načrte za obzidje treh naselbinskih jeder Ljubljane (Stari trg, Novi trg in Mestni trg), potrjuje vpliv, ki ga je imela vojska na razvoj mesta v preteklosti (za pregled glej Mantuani, 1937; Tomažič, 1937, in Voje, 1984). Naselbinska jedra Stare Ljubljane so se razvila na eni od najpomembnejših strateških točk tega dela Evrope, imenovani Ljubljanska vrata (na primer Slabe, 1984; Fister, 1986, in Gruden, 1992). Ker je imela ta točka v vojaškem smislu osrednjo vlogo v omrežnem naselbinskem sistemu, je bila pomembna za vse vojske, ki so se v preteklosti bojevale na tem območju. Nahaja se na izjemni geografski legi, to je na križišču zelo pomembnih kopnih in vodnih poti, na zoženem prehodu, ki ga na tem mestu oblikujejo znižane gore, kar pomeni, da je edini mogoči prehod iz Panonske nižine proti Italiij (glej Puš, 1984, ali Šašel, 1984). Franc Tomažič (1937) je zapisal, da se v Ljubljani z leve strani Rožnik nadaljuje v Polhograjskem hribovju in neprehodnih Julijskih Alpah, z desne pa se pogorje Golovca razširi v razgibano gričevje in dinarsko-kraški svet. Ljudmila Plesničar-Gec (1984: 11) navaja, da so »vsi raziskovalci najstarejše zgodovine Ljubljane poudarili pomembno geografsko lego mesta, ki je bila vzrok za neprekinjeno poselitev njenega ožjega območja v obdobju zadnjih štiri tisoč let «. Glavno raziskovalno vprašanje tega članka je: ali so pri izbiri lokacije za prvo naselbinsko jedro mesta na desni obali Ljubljanice (Stari trg) prevladali samo neznani naključni lokacijski kriteriji za razvoj urbane naselbine ali pa so na to izbiro vplivali predvsem strateški razlogi z vidika strateške urbane preventive.

\section{Izhodišča raziskave}

O simbiozi strateškega urbanega območja, ki ga obravnavamo v članku, do tega trenutka ne obstajajo nobene podrobnejše znanstvene raziskave, čeprav se Ljubljana nahaja na zelo pomembni geografsko-strateški legi tega dela Evrope, zaradi katere je bila izpostavljena vplivom različnih vojsk. Obstaja pa bogato zgodovinsko, arheološko, urbanistično, arhitekturno in drugo umetniško gradivo o mestu, še posebej o stari rimski Emoni, vendar v njem ni mogoče zaslediti jasnih navedb o vplivu vojn in strateških načel na urbanizem in prostorski razvoj današnjega mesta. Relevantnost navedenega gradiva je kljub temu nezamenljiva in nepreklicna. Brez njega sploh ne bi imeli možnosti za poglobitev že obstoječih spoznanj, kaj šele, da bi analizirali, razpravljali in pisali o tej temi. Že študija in analiza omenjenega gradiva sta nas privedli do želenega cilja, to je do nadaljnjih raziskav ter novih znanstvenih spoznanj o vzroku naselitve in poznejšem razvoju $\mathrm{v}$ mesto, ki ni bil naključen dogodek, temveč ima svojo osnovo prav v strateški pomembnosti. Ta izvira še iz časov starih Rimljanov, zaradi česar je bila vojska tukaj stacionirana - z manjšimi prekinitvami - že pred več kot dva tisoč leti. Prvi urbanistični načrti, ki obstajajo za naselbinska jedra Ljubljane (Stari trg, Novi trg in Mestni trg) in so jih naredili že v uvodu omenjeni vojaški strokovnjaki (Angielini, Pieroni in Stier), so nas spodbudili in nam dali podlago za raziskavo o vplivu strateškega oziroma vojaškega vidika.

\section{Metoda}

Raziskava, ki smo jo izvedli, je bila zgodovinsko-longitudinalna, kvalitativna in pluralna študija o vplivih vojne na razvoj posameznih mest in njihovo urbanistično oblikovanje in o načinu pristopa $\mathrm{k}$ njihovi fizični ali strateški zaščiti. Raziskava je zajela časovni okvir od prazgodovine do oblikovanja trojnega naselbinskega jedra Stare Ljubljane (Stari trg, Novi trg in Mestni trg). Raziskali smo vplive vojn in vojnih dejavnosti na razvoj prazgodovinskih koliščrskih naselbin in naselbin na gričih, razvoj Emone in njenih cestnih povezav, razvoj naselbinskih jeder in strateškega obzidja Stare Ljubljane ter kako so ti vplivali na urbanizem in arhitekturo mesta. Da bi se čim bolj približali reševanju predstavljene problematike, je bilo treba poiskati način, $s$ katerim bi urbane spremembe kar najslikoviteje predstavili v času, tako na območju današnje Ljubljane kot tudi na območju Evrope, Sredozemlja in Bližnjega vzhoda. Izkoristili smo model, ki ga $\mathrm{v}$ arhitekturi in urbanizmu uporabljamo kot osnovni element za razlago in pojasnjevanje, to je talni načrt ali tloris. Za to smo se odločili zato, ker nam talni načrti (tlorisi) podajajo najverodostojnejšo sliko arhitekturnih in urbanističnih dosežkov in procesov razvoja v okvirju določenega geografskega prostora. Prek časovnih in prostorskih plasti navedenih ozemelj (časovno-prostorski tlorisi) smo prišli do zgodovinskih, arheoloških in drugih podatkov, ki vsak po svoje odkrivajo sliko preteklih dogodkov in procese njihovega razvoja. Ker strateški vplivi in strateška urbana preventiva v obstoječi literaturi o urbanizmu in arhitekturi Ljubljane niso bili zadovoljivo obdelani, smo vse pomembne vrednote, ki se nanašajo na strategijo $\mathrm{v}$ širšem prostoru, analizirali in medsebojno primerjali, na osnovi novih dognanj pa smo sprejeli nove sklepe. Glede na to, da so ti procesi potekali na osnovnih ravneh, na katerih so zgrajena naselja in mesta, ter da smo na njih najlažje ugotavljali urbanistični razvoj in spremembe ter primerjali in analizirali dosežke $\mathrm{v}$ retrogradnem prostoru današnje Ljubljane z drugimi prostori, ki so že bili omenjeni, smo jih imenovali časovno-prostorski tlorisi (slika 2).

Časovno-prostorski tlorisi so pravzaprav horizontalni prerezi $\mathrm{v}$ določenem prostoru in času, ki se $\mathrm{v}$ plasteh nalagajo drug na drugega in so nam omogočili, da lahko sočasne zgodovinske, strateške, arhitekturne, urbane in ostale dosežke v širšem prostoru primerjamo z dosežki pri nas. Pri raziskavi smo uporabili še druge strokovne izraze, ki so nam omogočili, da čim preprosteje in nazorneje predstavimo slike razvojnih dogodkov 


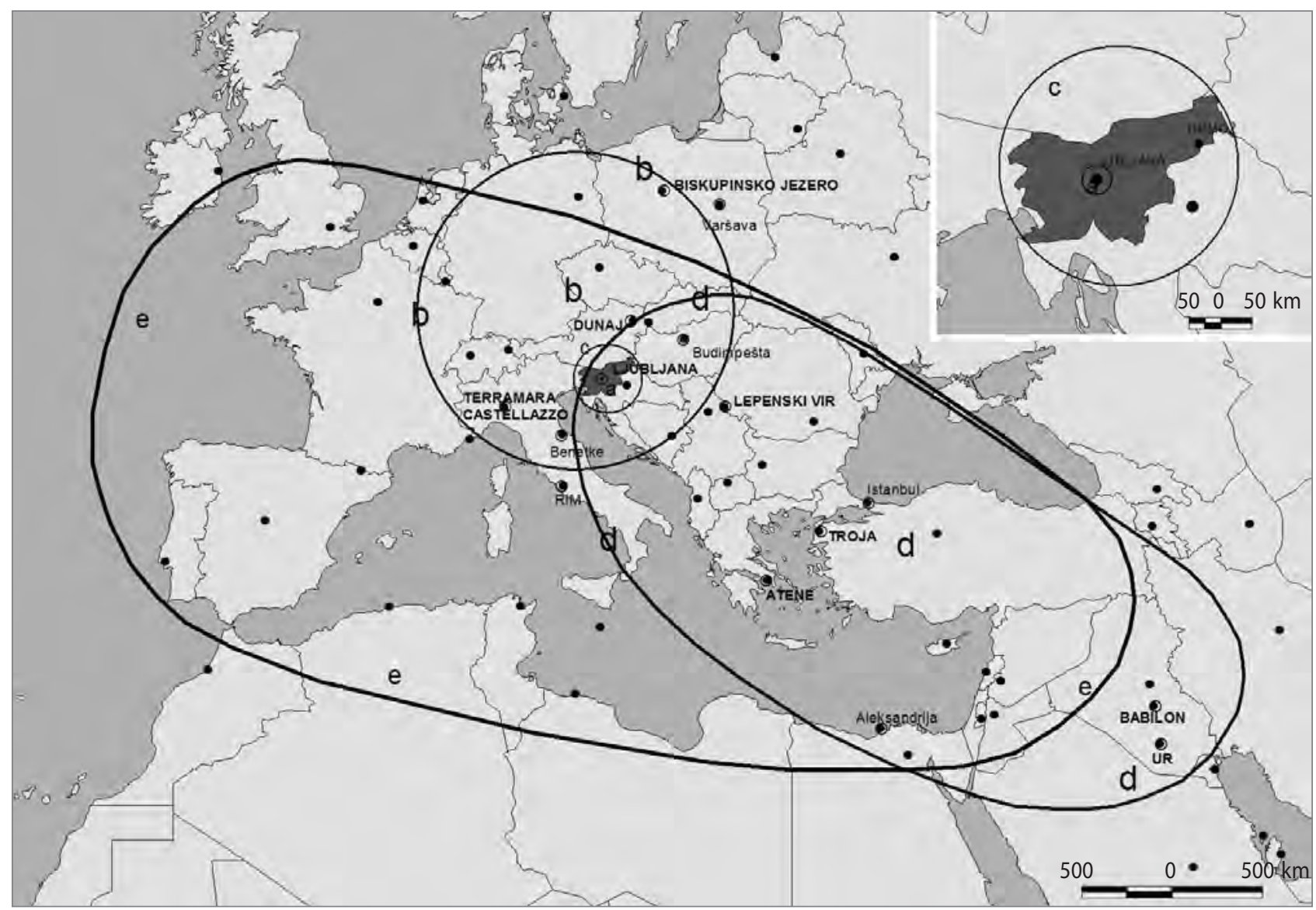

Slika 2: Časovno-prostorski tlorisi (a) Ljubljane, (b) Evrope, (c) Slovenije, (d) Sredozemlja in Bližnjega vzhoda ter (e) Rimskega imperija (vir: Šarac, 2013)

človeka v preteklosti, vključno s strateškimi pogoji v različnem času in prostoru. Ti strokovni izrazi so: 1. strateška urbana preventiva, ki je skupek strateških, urbanističnih, arhitekturnih ter drugih zamisli in veščin, $s$ katerimi se je človek fizično šcitil pred vojno agresijo v preteklosti, in 2. strateški vplivi, med katere spadajo vojaške napadalne ali obrambne izkušnje pri razvoju naselij, ki so se nenehno prenašale med različnimi geografskimi prostori in se uveljavljale v novih okolišcinah. Pri tem se nismo poglabljali v vse segmente urbanizma ali zgodovine, ampak samo v tiste, ki so $\mathrm{z}$ vojnami in $s$ strateško urbano preventivo povezani v tolikšni meri, da je to ugotovljivo še danes. Vojske, vojne in urbanizem sicer niso imeli in nimajo nikakršne medsebojne organske povezave, glede na to, da se prvi ukvarjata z uničevanjem človeka in njegovih uresničenih vrednot, slednji pa z osnovnim načelom humanega načrtovanja človeškega življenja v prostoru. Kljub temu pa so med njimi obstajale pomembne stične točke, ki se jim ni dalo izogniti in se nanašajo na različne dejavnike, ki smo jih $\mathrm{v}$ tem članku poimenovali strateška urbana preventiva. Ugotovili smo, da se je človekova samozaščita ali strateška urbana preventiva med njegovim zgodovinskim razvojem oblikovala na različne načine. Predvsem je bila odvisna od pogojev, ki jih je nudila narava, poleg tega pa tudi od iznajdljivosti in domišljije posameznikov, orožja in ostalih sredstev, $s$ katerimi so se branili ali bili na- padani v preteklosti. Z vidika strategije in urbanizma spadajo v strateško urbano preventivo: 1. izbira lokacije za naselbino, ki bi morala biti na kraju, ki je nasprotniku težko dostopen; 2. orisovanje zaščitnega oboda naselbine in njegova izgradnja; 3. izgradnja zaščitnih jarkov za vodo okrog oboda ter vse drugo, kar spada v urbano in strateško dejavnost.

\section{Rezultati raziskave in diskusija}

$S$ pomočjo zgodovinske vertikale, to je skozi čas in prostor, ali $\mathrm{z}$ analizo in $s$ primerjavo časovno-prostorskih tlorisov, ki smo jih obravnavali, smo ugotovili, da je strateška urbana preventiva pomembno vplivala na prostorski in urbanistični razvoj različnih mest, tudi na razvoj Ljubljane. Na osnovi ugotovljenih spoznanj smo dognali, da je prvo naselbinsko jedro Ljubljane (Stari trg) nastalo prav pod strateškim vplivom, to je po načelih strateške urbane preventive. Ugotovili smo tudi, da se je naselbina oblikovala v zgodnjem fevdalizmu, to je v obdobju preseljevanja ljudstva, in da so jo naši oboroženi predniki ustanovili kot kmečko-vojaško naselbino. Po naših ugotovitvah se je tudi tretje naselbinsko jedro Ljubljane (Mestni trg) razvilo na podlagi strateške urbane preventive, čeprav v drugačnih zgodovinskih okoliščinah. 


\subsection{Analiza in primerjava}

Iz zgodovinsko dognanih dejstev je razvidno, da se je človek že pri svojih prvih posegih v prostor (prazgodovina), to je od svojih prvih naselbin naprej, ko je prenehal nagonsko iskati svoja naravna zaklonišča in jih je začel zavestno graditi ter $\mathrm{v}$ njih stalno živeti, pričel tudi zavestno zaščitno ali preventivno varovati. To človekovo varovanje je pravzaprav posledica strahu pred nasilno smrtjo, do katere po navadi pride $\mathrm{v}$ vojnih spopadih. Medtem ko je človek s pomočjo poganskega in pozneje religioznega verovanja našel rešitev v namišljenem svetu in je biološko smrt sprejel kot posmrtno življenje (glej Puš, 1984), se je moral pred nasilno smrtjo nenehno varovati. To je uresničeval z življenjem $\mathrm{v}$ skupnosti ter vsemi naravnimi in fizičnimi sredstvi, ki so mu bila na voljo. Kot primer navajamo eno prvih sedentarnih naselbin človeka v naši bližini - arheološko nahajališče Lepenski vir ob Donavi pri Đerdapu v Srbiji iz 4. tisočletja pr. n. št. (glej Maksimović, 1972, ali Bogdanović, 1976). O tem tudi Fedja Košir (1993: 26) navaja, da »ni nelogično, da so v aglutinantni gruči prvenstveno pomembni elementi, ki bi morali zagotoviti varnost. Dokaj zanesljivo jo jamči že zgoščena zazidava, ki doseže vrhunec v mitičnem kaosu labirintnosti. Zgoščenost (aglutinantnost) pomeni predvsem še težjo orientacijo, saj samo domačini vedo, kako se da $\mathrm{v}$ takih naselbinah ,komunicirati" «.

Že pri prazgodovinskem prostorskem tlorisu območja današnje Ljubljane opažamo paradoksalen položaj. Ugotavljamo, da v bližini naravnega stičišča pomembnih prometnih žil (»jantarska pot «), ki naj bi že takrat usmerjale materialne in kulturne tokove, ki so vodili iz Panonije proti Sredozemlju in z Balkana proti Zahodni Evropi, ni obstajala nobena naselbina (glej Gruden,1992; Plesničar-Gec, 1984; Puš, 1984, ali Vilfan, 1984). $\mathrm{Na}$ osnovi tega bi lahko sklepali, da takrat prostor križǐšča v nižinskem delu Ljubljanske kotline, najverjetneje iz strateških razlogov, ni bil preveč zanimiv niti primeren za naseljevanje. To pravzaprav dokazuje, da v takratnem času človek na teh prostorih še ni imel dovolj izkušenj s področja strateške urbane preventive, da bi si svojo naselbino upal locirati in razvijati na nižinskem delu Ljubljanske kotline, tam, kjer bi imel najboljše pogoje za poljedelstvo, živinorejo in drugo. Iz strateških razlogov in pod strateškim vplivom tovrstnih evropskih izkušenj je takratni človek svoje naselbine lociral daleč od prometnega križǐšča, to je na obrobju Ljubljanskega barja, ki je bilo okrog leta 2000 pr. n. št. še jezero (slika 3a).

Poleg koliščarskih naselbin na Barju, ki so doslej najstarejše znane predhodnice Ljubljane, lahko kot take opredelimo tudi manjše naselbine pri Malem grabnu na Prulah in druge (glej Stele, 1939). Tatjana Bergant (1984) ugotavlja, da je specifičnost Ljubljanskega barja pogojevala gradnjo koliščarskih naselbin z značilno arhitekturo, ki je bila najbrž že diferen-
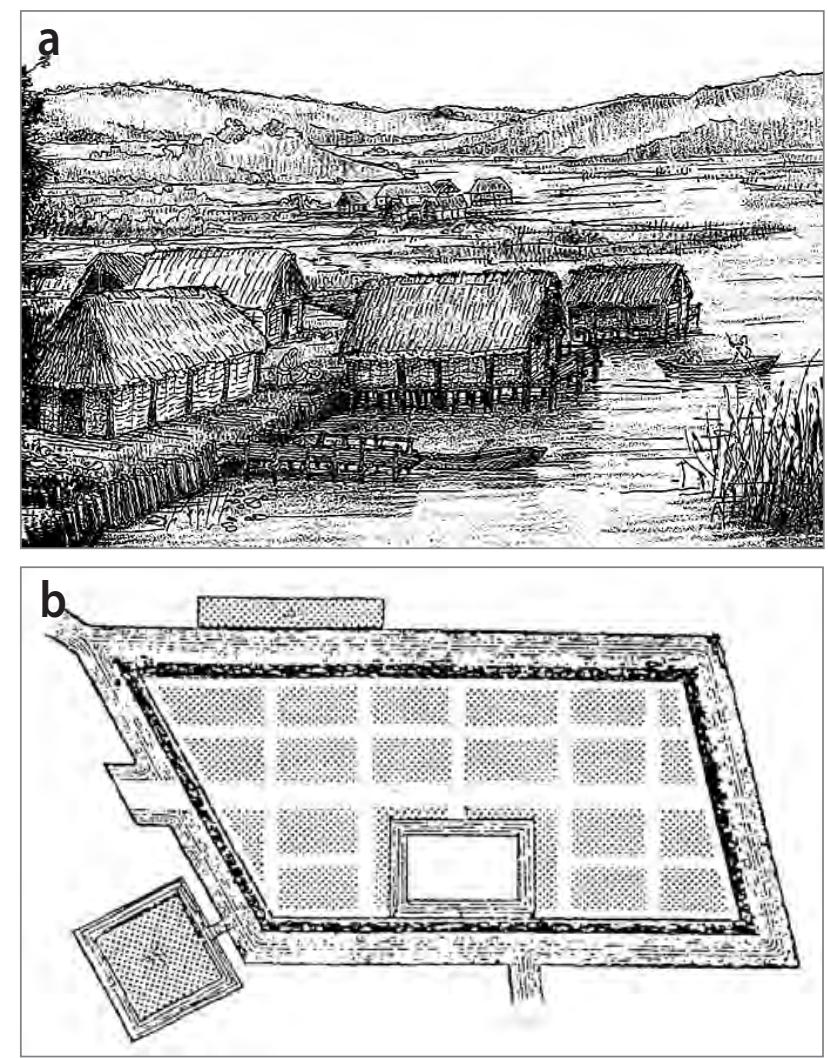

C

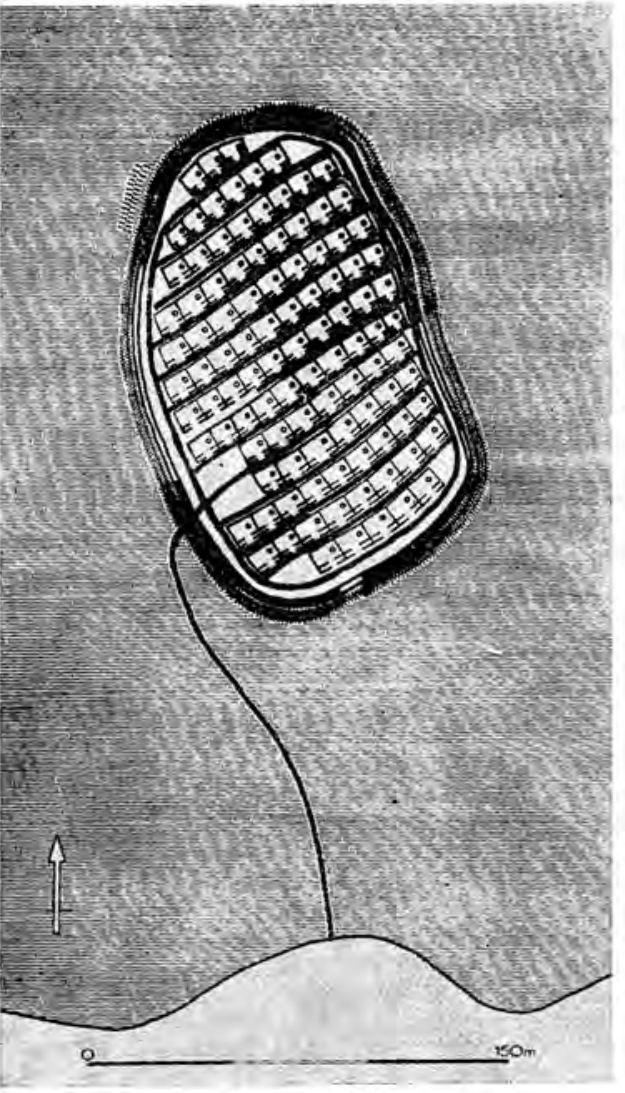

Slika 3: (a) Koliščarska naselbina na Ljubljanskem barju - rekonstrukcija; (b) koliščarsko naselje Terramara Castellazzo v Italiji, 2. tisočletje pr. n. št.; (c) otoška naselbina na Biskupinskem jezeru, 6.-5. stoletje pr. n. št. (viri: (a) Fister, 1986; (b) Košir, 1993; (c) Maksimović, 1972) 


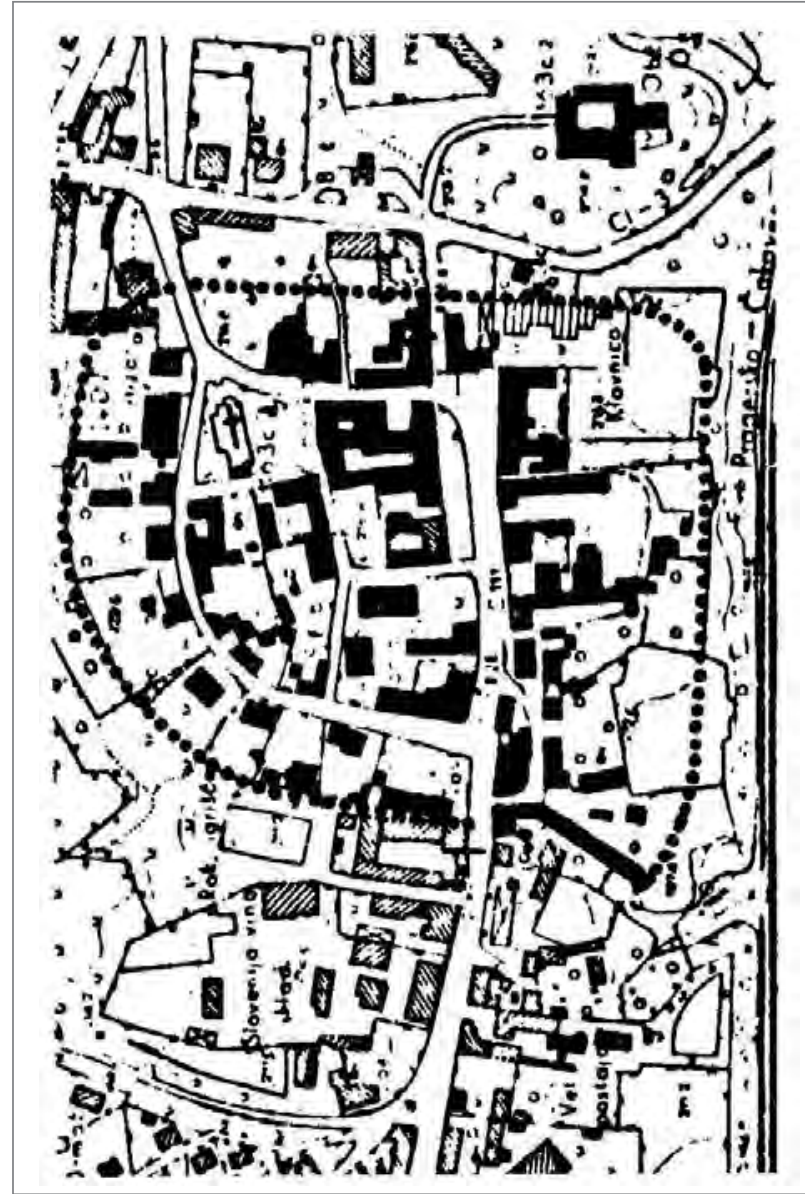

Slika 4: Tlorisni obseg prazgodovinskega mesta Ormož leta 1000 pr. n. št (vir: Fister, 1986)

cirana po premoženju, kar naj bi potrjevalo tudi razvoj vojaške aristokracije. Veliko podobnih koliščarskih naselbin se je oblikovalo tudi drugod po Evropi (Švica, Italija, zahodna Avstrija, vzhodna Francija, Posavina na Hrvaškem in podobno), nastale so prej ali pa sočasno kot pri nas, vendar so se pri njih popolnoma drugače udejanjila načela strateške urbane preventive. Najbolj znana koliščarska naselbina je Terramare Castellazzo v Italiji, ki je nastala v bronastem obdobju, okrog leta 2000 pr. n. št. (slika 3b). Po nekaterih trditvah, ki niso natančno raziskane, naj bi notranjost naselja poleg zunanjega oboda z leseno palisado že takrat imela resnično zasnovo z notranjo vsebino. V zgodnji železni dobi, v 6.-5. stoletju pr. n. št., je nastala otoška naselbina na Biskupinskem jezeru na Poljskem (glej Maksimović, 1972, ali Košir, 1993), ki je poleg tega, da je stala na vodi, imela tudi strateške urbane preventivne obodne zidove, ki so bili zgrajeni iz trivrstne hlodovine, zapolnjene z zemljo (slika 3c). Okrog leta 1300 pr. n. št. pa so na gričih okoli današnje Ljubljane, natančneje na težko dostopnih vzpetinah, nastajale gručaste naselbinske tvorbe brez kakršnih koli zasnov (glej Gruden, 1992).

Izkušnje s področja strateške urbane preventive pri oblikovanju naselbin pri nas potrjujejo tudi ugotovitve na podlagi časovno-prostorskega tlorisa, in sicer na popolnoma drugem koncu današnje Slovenije. Naselbina pri Ormožu je nastala okoli leta 1000 pr. n. št., to je skoraj tisoč let po koliščcarskih naselbinah na Barju in tristo let po naselbinah na Grajskem griču, in naj bi bila ena od prvih urbanih naselbin pri nas. Peter Fister (1986) navaja, da se je nahajala na veliki naravni planoti nad reko Dravo in da je bila velika okoli 300 krat $400 \mathrm{~m}$. Utrjena naj bi bila s $5 \mathrm{~m}$ visokim nasipom, ki je bil okrepljen z leseno palisado, in s $6 \mathrm{~m}$ globokim jarkom. Notranjost je bila bogato urejena, lesene hiše so povezovale pravokotno križane in tlakovane ceste, naselbina pa je po svoji velikosti in vsebini presegla celo poznejše srednjeveško mesto. $Z$ vidika strateške urbane preventive je to nižinsko naselje zanimivo zato, ker je poleg nasipa z leseno palisado, ki je obkrožal celotno naselbino, imelo tudi globok zunanji jarek (slika 4).

Pri analizi širših prazgodovinskih prostorskih tlorisov smo ugotovili, da so bile naselbine v Vzhodni Evropi, Sredozemlju in na Bližnjem vzhodu v splošnem bolj razvite, naprednejše ter na višji stopnji civilizacijskih in kulturnih dosežkov kot tiste pri nas in v Zahodni Evropi. V času naših koliščarskih naselbin na Barju in podobnih po Evropi so v Egiptu (2778-2263 pr. n. št.) gradili zelo pomembne kompleksne arhitektonske kompozicije: grandiozne hrame v Luksorju in Karnaku ter Keopsovo, Kefrenovo in Mikerinosovo piramido, kar potrjuje obstoj namišljenega sveta $\mathrm{z}$ verovanjem $\mathrm{v}$ posmrtno življenje. Imeli so tudi ogromna mesta: Tebe, za katere menijo, da so bile zgrajene na desni strani Nila med omenjenimi svetišči $\mathrm{v}$ dolžini $12-15 \mathrm{~km}$ in naj bi bile tudi sedež faraonov; Kahun (19. stoletje pr. n. št.), mesto pravokotne osnove s površino okoli 10 ha, ki je bilo ograjeno z opečnatim zidom in namensko zgrajeno za namestitev graditelja piramide Ilahuna, in Ahetaton (leta 1400 pr. n. št.), mesto, ki je bilo ustanovljeno kot nova politična in verska prestolnica Egipta (glej Maksimović, 1972, ali Košir, 1993).

Nekoliko drugačen je bil položaj leta 3000 pr. n. št. v Babiloniji. Razlika ni opazna samo v arhitekturi in urbanizmu mest, ki so se že v tistem času gradila načrtovano, ampak tudi v zelo razvitem občutku za strateško urbano preventivo. Njihova mesta so se večinoma gradila ob rekah in glavnih poteh ali na njihovih križiščih z obrambno-razglednimi terasami, ki so bile zgrajene na več ravneh zaradi zaščite pred poplavami in psihološke ločitve božanskega od človeškega. Na teh terasah so gradili pomembne objekte (hrame in dvore), do katerih so vodile stopnice. Mesta so imela že takrat urejeno mestno kanalizacijo in vodovod, kar potrjuje visoko stopnjo splošne in gradbene kulture. Pri gradnji teh mest so upoštevali strateško urbano preventivo, ki se je zaradi nenehnega vojskovanja stalno izpopolnjevala. $S$ tega vidika je še posebej zanimivo mesto Ur (2300-2200 pr. n. št.), za katero menijo, da je že takrat štelo okrog pol milijona prebivalcev. Poleg mestnega obzidja 
in jarka, ki sta obkrožala to mesto ovalne oblike, je obstajalo še dodatno notranje obzidje z jarkom okrog pravokotnega kompleksa svetišča in vladarjeve palače (slika $5 \mathrm{a})$ ). V nekaterih starih mestih iz tega obdobja (Asur in Niniva) se je vladarjeva palača nahajala na robu mestnega obzidja, tik ob reki, verjetno zaradi možnosti lažjega pobega (glej Maksimović, 1972, ali Košir 1993).

Poseben pomen v tej skupini mest ima vsekakor načrtno zgrajen Novi Babilon (7.-6. stoletje pr. n. št., okrog 200.000 prebivalcev), ki je takrat veljal za »središče sveta «. To mesto ni znano le zaradi svojih čudežev svetovnega pomena, kot so Semiramidini terasasti viseči vrtovi in $90 \mathrm{~m}$ visok zigurat, ki ga poznamo pod imenom Babilonski stolp, ampak tudi zaradi atraktivnih urbanističnih in strateških urbanih preventivnih strukturnih prvin. Te strukture so zanimive tudi zato, ker so se izoblikovale skoraj sočasno s tistimi ključnimi urbanističnimi gibanji, ki nakazujejo skorajšnjo temeljito metamorfozo sestavov v celotnem evropskem prostoru; tem procesom so lahko celo morebiten vzor. Mesto pravzaprav ni novo, saj ga je po uničevalni zmagi nad Asirci obnovil kralj Nebukadnezar. Nahaja se na obeh straneh reke Evfrat in je dokaj pravokotne oblike (slika 5b). Razdeljeno je v kvadrante, ki so z mrežo ravnih ulic povezani z avenijo procesij, ta pa od veličastnega vhodnega portala z dvojnim zidovjem pelje skozi novi del mesta na desni strani (velikost okrog 1.600 krat $1.600 \mathrm{~m}$ ), ki ga z mostom čez reko Evfrat poveže s starim delom mesta na levi strani. Celotno mesto obkroža dvojno obzidje z globokimi kanali za vodo. To dejstvo potrjuje, kako pomembna je bila strateška urbana preventiva za normalen razvoj tega mesta in njegovo obrambo pred vojskami, ki jim je bilo ves čas izpostavljeno vse do makedonske zasedbe z Aleksandrom Velikim in požiga leta 330 pr. n. št.

Ko je prišel na oblast Aleksander Veliki, se je začelo obdobje helenizma in njegove kolonizacijske ekspanzije. Prišlo je do pomembnih sprememb $\mathrm{v}$ arhitektonski in urbanistični sestavi in sklopu novih kompozicijskih konceptov mest, domneva pa se, da naj bi do teh prišlo tudi zaradi sočasnih zgledov s Starega vzhoda. O teh spremembah je Košir (1993: 67) zapisal: »Težko, da vse to ne bi rabili za model. Gigantski mozaik peržanske države namreč kasneje predstavlja inkubacijsko ,toplo gredo', v kateri se ugnezdi in razbohoti zmagoviti helenizem - $s$ čimer se začne druga faza, tako imenovana klasična faza sužnjelastniške formacije.« Do takrat naključno grajeno komunikacijsko omrežje $s$ krivim ulicami nadomesti discipliniran in standardiziran ortogonalni raster. Ta končno dozori v klasiki, v kateri sta struktura in kontura uglašeni $v$ »čisto « obliko, razširi se na evropski Zahod, kjer jo prevzame rimski urbanizem, ki je sinteza vse antike. Strateška urbana preventiva je postala zelo pomemben dejavnik pri izbiri lokacije za graditev mest po novem sistemu. Lokacije so se določale na krajih, ki so veljali za
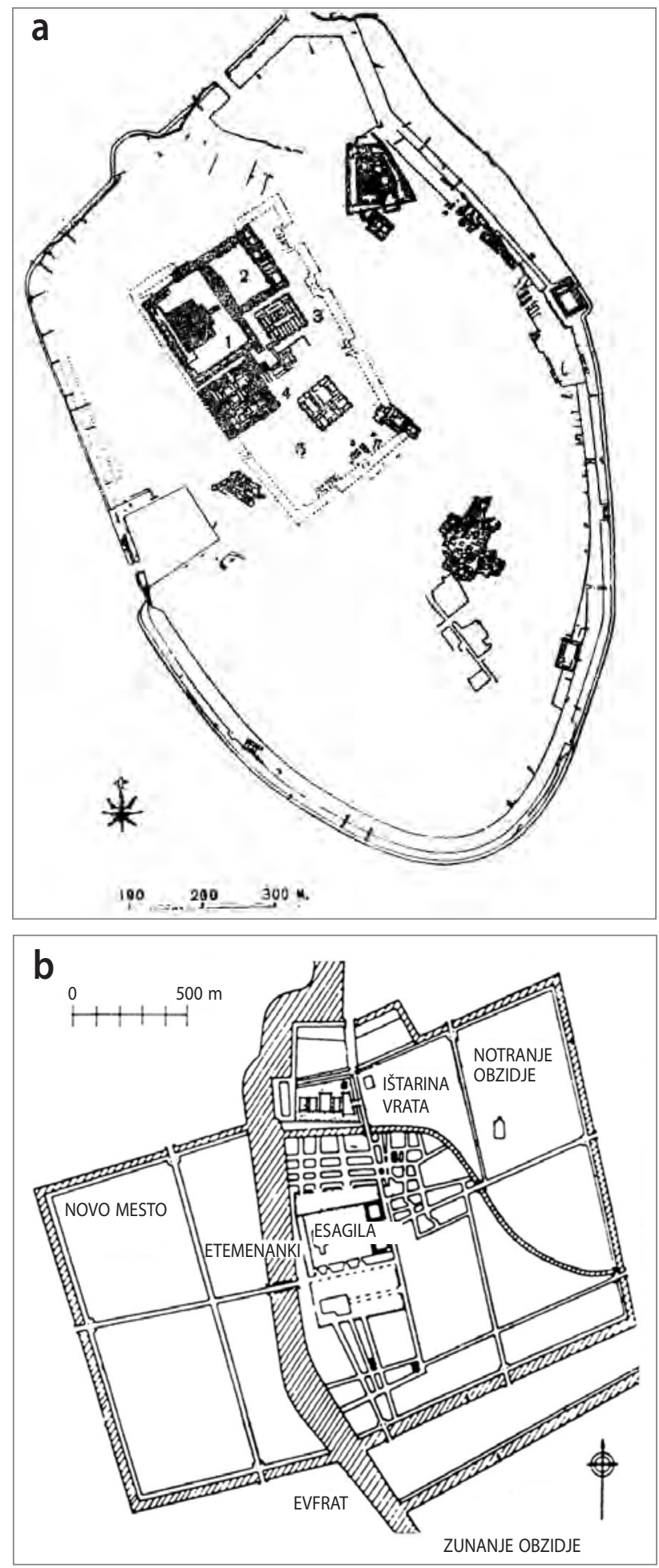

Slika 5: (a) Tloris sumerskega mesta Ur, 2300-2200 pr. n. št.; (b) tloris Babilona, 6. stoletje pr. n. št. (viri: (a) Maksimovič, 1972; (b) Košir, 1993)

strateško najvarnejše, to je ob obali morja. Taki mesti sta na primer Pirej, največje vojno in trgovsko pristanišče Atencev, o katerem so dajali mnenja največji umi tega časa, kot na primer Aristotel in drugi, ter Aleksandrija, ki se nahaja na morski obali med lagunama, nad njo pa se je navduševal Aleksander Veliki (glej Maksimović, 1972, ali Košir, 1993). 
Med bogatimi urbanimi dosežki v Sredozemlju bomo posebej poudarili Trojo, o kateri obstaja večplastno arheološko gradivo (2300-1100 pr. n. št.) in katere notranja struktura se je $\mathrm{v}$ času nenehno preoblikovala vse do nastanka mesta z vsemi urbanističnim prvinami, ki so takrat simbolizirale mesto, ne glede na njegovo velikost, ampak glede na njegovo vsebino (glej Bogdanović, 1976). V rekonstruiranem tlorisu Troje, ki smo ga prevzeli od Koširja (1993), je močno poudarjeno pet prostorskih prvin, ki nam bodo zadostovale za razlago in primerjavo v tem delovnem gradivu, in sicer: 1. lega, 2. obod, 3. sistem hierarhično členjenih komunikacij, 4. zazidalno tkivo in 5. arhitektura » posebnega pomena «. Na podlagi tega lahko sklepamo, da sta lokacija (pravzaprav njena izbira) in zaščitni obod osnovna elementa strateške urbane preventive, kar smo že lahko videli tudi pri babilonskih mestih in koliščarskih naseljih v Evropi. Zato bomo te strateške urbane elemente tlorisa $\mathrm{v}$ nadaljnjih analizah in primerjavah uporabljali kot šolski primer urbanističnega sklopa (slika 6).

Če Trojo - ne glede na geografsko oddaljenost, kulturološki razvoj in strukturno vsebino naselbine $-\mathrm{z}$ varnostnega vidi$\mathrm{ka}$, to je $\mathrm{z}$ vidika strateške urbane preventive, primerjamo $\mathrm{s}$ koliščarskimi naselbinami pri nas (leta 2000 pr. n. št.) in z naselbino na Grajskem griču (leta 1300 pr. n. št.), lahko pridemo do sklepa, da so vse imele podobne prvine. Izbira lokacije za naselbine (kar pomeni urbanistično dejavnost) je osnovni preventivni strateški element posega v prostor. Koliščarske naselbine so bile postavljene na vodi, druge naselbine pa na gričih. Drugi element strateško urbane preventive, to je varnost oboda naselbine, je bila pri koliščarskih naseljih voda, pri gričih pa nasip iz natlačene ilovice. To pomeni, da se je človek v svojem

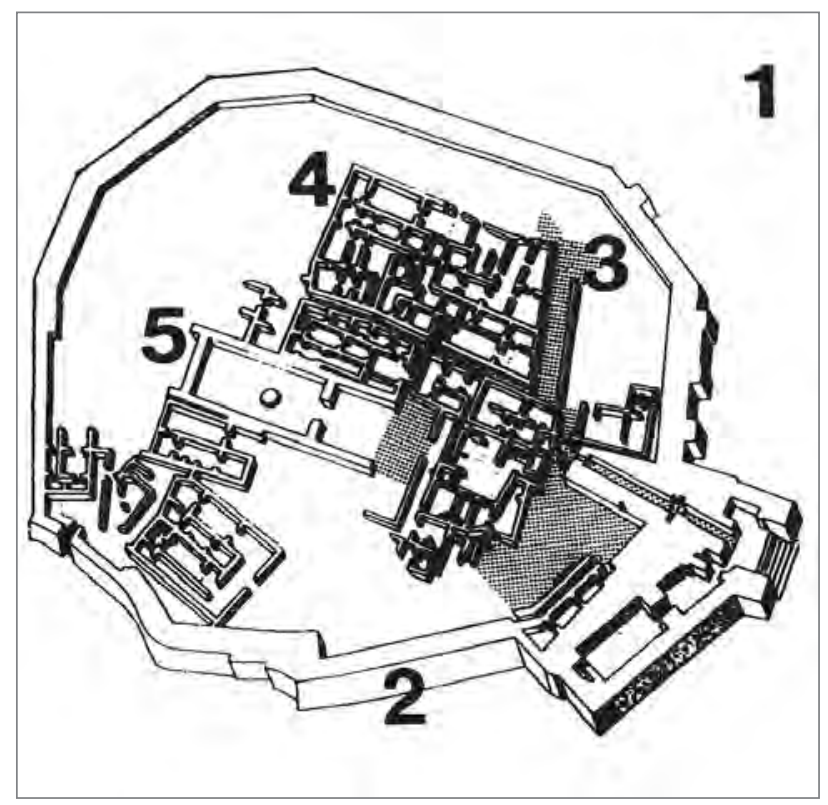

Slika 6: Prostorske prvine v rekonstruiranem arheološkem tlorisu Troje: 1. lega, 2. obod, 3. sistem hierarhično členjenih komunikacij, 4. zazidalno tkivo in 5. arhitektura »posebnega pomena« (vir: Košir, 1993) zgodovinskem razvoju z vidika strateške preventive nenehno poskušal čim bolje zaščititi tako, da je za svojo naselitev izbiral lokacije, ki so vključevale največje ovire za napadalce ter $s$ tem kar najbolje ščitile naselbino in njene prebivalce.

\subsection{Prvi načrtni urbanistični posegi na prostoru današnje Ljubljane}

Prostorski tloris, na katerem se danes nahaja sodobna Ljubljana, se je prvič začel načrtno, to je urbanistično, spreminjati na prelomnici med starim in novim štetjem, $\mathrm{z}$ vojnim pohodom vojakov 11. rimske legije Apolinaris po Vipavski dolini in zasedbo tega kraja. Prav rimski legionarji so se prvi zavedeli strateške pomembnosti te geografske lege (na primer Tomažič, 1938; Slabe, 1984; Fister, 1986, in Gruden, 1992), zasedli ta prostor in s pomočjo enot, ki jih še danes imenujemo »inženirske enote « (glej Fister, 1986), tukaj zgradili mesto, ki se je imenovalo Emona. Lahko bi rekli, da je bila Emona grajena po določenem tipskem načrtu, ki je določal strogo pravokotno obliko v velikosti 523,6 krat $435,5 \mathrm{~m}$ ter so ga Rimljani uporabljali in prilagajali pri izgradnji postojank za svoje legije, na primer Castra Vetera ob Renu, Novaesium v Porenju, Vindonissa v Švici in Vindobona na Dunaju (glej Schmid, 1941). Pri izbiri lokacije in izgradnji mesta so uporabili vse do tedaj pridobljene vzhodnjaške civilizacijske in strateške izkušnje. Čeprav naj bi bila po argonavtski legendi tukaj še pred prihodom Rimljanov emonska naselbina (za pregled glej Šašel, 1984, in Gruden, 1992), kot prvi pogoj strateške urbane preventive, so izbrali lokacijo na sotočju rek Ljubljanice in Gradaščice in njeno naravno danost izkoristili najprej za svojo zaščito, potem pa tudi za druge, poznejše potrebe. Obod okrog utrdbe, kot drugi pogoj strateške urbane preventive, je bil zgrajen iz kamenja, visok pa je bil približno od 6 do $8 \mathrm{~m}$ in širok od 2 do $4 \mathrm{~m}$. Imel je 26 stolpov, 4 glavne vhode (severni, južni, vzhodni in zahodni) in 10 stranskih, ki so jih pozneje iz varnostnih razlogov zazidali (glej Slabe, 1984). Nepogrešljiv element strateške urbane preventive so bili kanali za vodo okrog obzidja, ki so jih izkopali z zunanje strani. Posebnost Emone in tudi drugih rimskih naselbin iz tega obdobja je bila $\mathrm{v}$ tem, da je bilo mesto locirano v smislu nebesnega koordinatnega križa, to je vzhod-zahod in sever-jug, in tako sta bili postavljeni tudi glavni ulici mesta: Decumenus maximus - današnja Rimska cesta (vzhod-zahod) - in Cardo maximus - današnja Slovenska cesta (sever-jug). Glavni vhodi v mesto so povezovali ceste, ki so vodile iz smeri Rima, Via Iulia Augusta (današnja Tržaška cesta), iz smeri Balkana (današnja Karlovška cesta), iz smeri Panonije (današnji Slovenska in Dunajska cesta) in iz smeri severozahoda (današnja Celovška cesta). Notranja vsebina utrdbe je imela v dokončni obliki meščansko naravo. Bila je urbanistično razdeljena $\mathrm{v}$ pravokotne in kvadratne stanovanjske enote (insule) s pravokotno ulično mrežo in $\mathrm{z}$ osrednjim delom - forumom -, to je mestnim trgom, kar je bilo nekaj 
novega v urbanističnem sklopu mesta v primerjavi z mesti Starega vzhoda. Pravzaprav so Rimljani v urbanizmu in arhitekturi Emone izrazili vse do takrat znane podobe antične civilizacije. S sprejetjem krščanstva so imeli Rimljani v Emoni tudi škofijski sedež (glej Bratož, 1984, ali Šašel, 1984). Emona je bila sicer po hunskem vojnem pohodu okrog leta 452 uničena, vendar so krakaste cestne smeri, ki jih je že pred dva tisoč leti zastavila rimska vojska, še danes ogrodje glavnih cest v sodobni Ljubljani (za pregled glej Tomažič, 1937, ali Vilfan, 1984). Poznejše notranje težave v rimski državi, nenehni boji za oblast ter vojne s Huni, z Goti, Langobardi, s Franki in Slovani so pripeljale do propada zahodnega rimskega cesarstva (glej Ciglenečki, 1992, ali Gruden, 1992). S propadom cesarstva se je končala tudi takratna sužnjelastniška ureditev, prišlo je do preseljevanja narodov (5.-6. stoletje), propada krščanstva v našem prostoru in nastanka nove družbene ureditve v Evropi, ki jo poznamo pod imenom fevdalizem. Kot je navedeno v Enciklopediji leksikografskog zavoda (glej Bogdanov idr., 1967), sta bili oblast in zemlja, kot materialna podlaga fevdalizma, takrat vertikalno razdeljeni na vladarja (cesarja) in podložnike (fevdalce) ali častne vojake. Blagovna menjava pa se je $\mathrm{z}$ denarne spremenila $\mathrm{v}$ naturalno. Fevdalci so morali, če je bilo to potrebno, s svojim vojaškim ljudstvom (kmeti), zbranimi iz selišč na svojem fevdu, braniti interese vladarja. Navaden kmet v zgodnjem fevdalizmu ni bil več suženj, ampak je predstavljal podrejeni razred. Moral je obdelovati zemljo, plačevati naturalni davek in se kot vojak tudi brezpogojno bojevati za svojega fevdalca ali vrhovnega vladarja, slednje za naše prednike do približno 9. ali 10. stoletja ni veljalo (glej Vilfan, 1984).

\subsection{Oblikovanje prvega naselbinskega jedra Ljubljane (Stari trg)}

Za naše sklepe so zanimivi predvsem časovno-prostorski tlorisi iz obdobja med 6. in 12. stoletjem, iz katerih je z zgodovinskega vidika očitno, da je na prostoru današnje Ljubljane nastala praznina. V tem času so na območje današnje Ljubljane najbrž prišli naši predniki, to je v obdobju konsolidacije Slovencev v zgodnjem srednjem veku (glej Sivec, 1984, ali Gruden, 1992). Glede na zgodovinsko praznino bi morali »prihod « svojih prednikov $\mathrm{v}$ te kraje dojemati zelo polemično, ker se je uresničeval med lokalnimi vojnami za ozemlje in oblast. Sicer pa so bila po propadu zahodnega rimskega cesarstva in hunske države po Atilovi smrti leta 453 zgodovinska dogajanja v vsem evropskem prostoru izjemno burna. Napačno bi bilo predvidevati, da so naši predniki nove kraje zasedli v prijateljskem vzdušju. $\mathrm{Na}$ ozemlje današnje Ljubljane so prišli predvsem kot kolonisti, za katere je zgodovinsko dobro znano, da so v nove kraje vedno prihajali z orožjem (glej Tancik, 1971, ali Gruden, 1992). Josip Gruden (1992: 40) o naših prednikih navaja: »Tu se nam naši predniki ne kažejo kot miroljuben narod, ki se peča le s poljedelstvom in živinorejo, temveč kot silen in bojevit rod, ki je drzno naskakoval mogočne države in si z orožjem osvojeval nove zemlje.« Cilj prihoda je bil jasen. Na koloniziranem ozemlju, ki je bilo v zadnjih štiri tisoč letih neprekinjeno naseljeno (glej Plesničar-Gec, 1983, Kos, 1985, ali Gruden, 1992), so s pomočjo sile in orožja najprej morali »počistiti prostor « (po vojaški terminologiji), da bi lahko potem ustanovili svojo naselbino, iz katere se je veliko pozneje razvila današnja Ljubljana. Zakaj so se naši predniki odločili za svoje prebivališče izbrati novo lokacijo, čeprav se jim je ponujalo veliko različnih lokacijskih možnosti za bivanje? Zgodovinsko je utemeljeno, da ruševin Emone niso obnavljali, čeprav bi imeli tam največ možnosti za bivalno namestitev, to je glede gradbenega materiala in že urejenih rimskih družinskih hiš s civilizacijskimi dosežki tega časa, kot so vodovod, kanalizacija, talno gretje in drugo. Za to se najverjetneje niso odločili zaradi maloštevilnosti skupine ali župe, ki se je naselila na tem območju, ali zaradi popolnoma drugačnega načina življenja, ki so ga poznali in se je močno razlikoval od zaprtega sistema rimske stanovanjske hiše. Župa je bila pravzaprav prvotna politična enota Slovencev, to je zveza sorodnikov, ki so bili skupaj naseljeni na nekem območju (glej Gruden, 1992). V nasprotju z našimi predniki, ki niso želeli obnoviti bivališ̌c svojih predhodnikov niti prevzeti njihovih bivalnih navad, je drugod po Evropi v tem času na območjih nekdanjih rimskih naselbin potekal proces krčenja posameznih mest (Firence in Bologna ali skrčki v arenah, na primer Perigueux, Tours, Nimes, Arles in podobno), ki so se krčila zaradi novih ekonomskih odnosov in možnosti boljše obrambe (slika 7; Košir, 1993).

Iz primera Emone je pravzaprav očitno, kar je tudi zgodovinsko utemeljeno, da so se naši predniki izogibali rimskim naseljem in so svoje naselbine raje ustanavljali v njihovi bližini (slika 8a). Ena od takih lokacij v bližini Emone, na kateri bi lahko gradili po svoje, je bila ravninska lokacija na križǐ̌ču skozi tisočletja pomembnih trgovskih smeri pri Ajdovšcini, danes lokacija Kavarne Evropa (glej Grafenauer, 1963, ali Vilfan, 1984). Ta naj bi imela najboljše pogoje za dejavnosti, $s$ katerimi so se

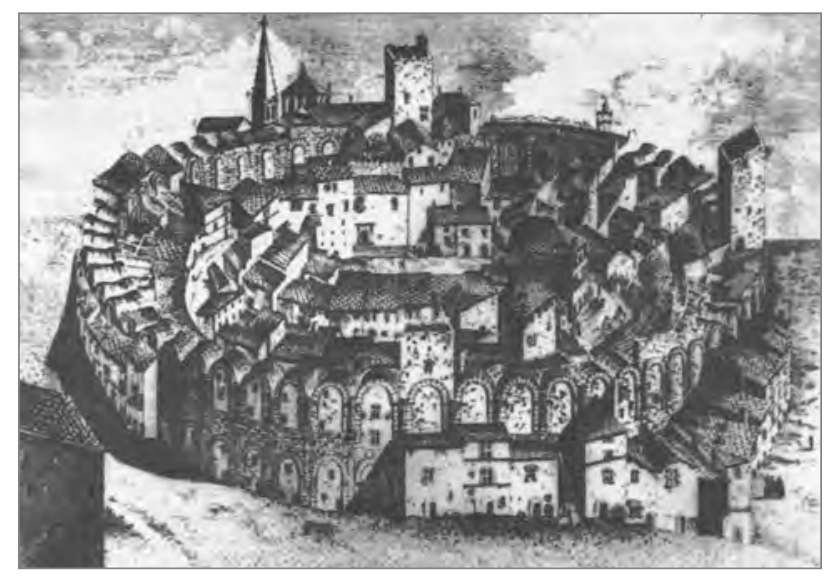

Slika 7: Pogled na srednjeveško jedro Arlesa: obod rimske arene, predelan v srednjeveško obzidje (vir: Košir, 1993). 

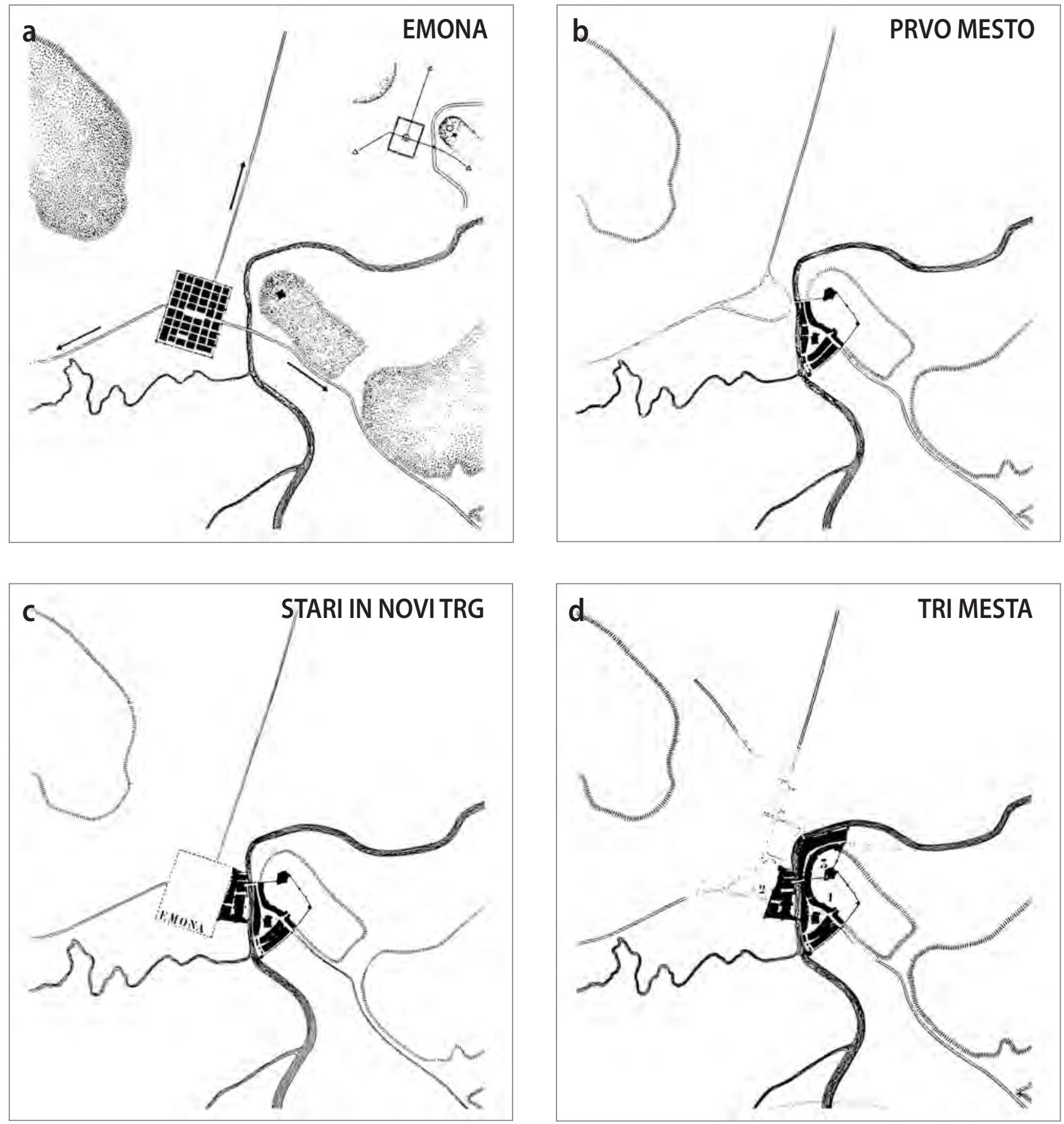

Slika 8: (a) Lega rimske Emone; (b) lega Starega trga; (c) lega Starega in Novega trga; (d) končna oblika trojnega naselbinskega jedra Ljubljane (Stari trg, Novi trg in Mestni trg) (vir: Stele, 1939)

ukvarjali, to je za poljedelstvo, živinorejo in drugo. Kot smo že ugotovili, bivanje na ravninskih območjih vse od prazgodovine naprej ni bilo varno, če niso bila predhodno zagotovljena vsa načela strateške urbane preventive. Če so torej Rimljani kot najmočnejša sila tega časa upoštevali to strateško dejstvo in so lokacijo Emone, kot smo lahko videli, dislocirali južneje od križišča na varnejše mesto, to je na sotočje rek Ljubljanice in Gradaščice, potem ne preseneča dejstvo, da so se tudi naši predniki izognili tej lokaciji. Za obnovo naselbin na Barju ali gričih, o katerih smo že razpravljali, niso imeli interesa. Naši predniki ali oboroženi ustanovitelji prihodnje Ljubljane so za svojo naselbino poiskali popolnoma novo lokacijo, za katero ni bila značilna kontinuiteta naseljevanja. Izbrali so strateško varno lokacijo, ki je bila oddaljena od križǐšča poti in jih ni omejevala pri kolektivnem načinu življenja niti pri kolektivni kmečki dejavnosti na poljedelski zemlji v bližini naselbine. Ob tem so izbrali tako lokacijo za naselbino (kar je mogoče videti še danes), ki je poleg že naštetih lastnosti vsebovala tudi elemente strateške urbane preventive, prilagojene orožju ter pripomočkom za napad in obrambo tistega časa. Določena je 
bila na desnem bregu Ljubljanice, na nasprotni strani ne tako oddaljene razrušene Emone. Anton Melik (1929-1930) meni, da je to naselje nastalo na sledeh in osnovi rimskih cest, pravilna zasnova talnega načrta naselja pa potrjuje, da ta lokacija do takrat še ni bila naseljena. Zanjo so se kot oboroženo ljudstvo najverjetneje odločili ob upoštevanju svojih strateških izkušenj, na podlagi katerih so izbrali lokacijo na težko dostopnem mestu, ki je imela glede na ostale lokacije, ki smo jih obravnavali, prav vse prednosti naravnih ovir (reka, grič in barje). Te ovire so kot elementi strateške urbane preventive zagotavljale strateško varnost in tudi možnost umika pri morebitni ogroženosti iz različnih smeri, kar je bila ena od posebnosti takratnih slovenskih naselbin (glej Fister, 1986) (slika 8b).

Pomemben element $\mathrm{v}$ raziskavi, ki do zdaj še ni bil omenjen, je grad na hribu, nad naselbino. Iz tega obdobja je zgodovinsko znano, da naši predniki pod vodstvom svojega plemstva niso uspeli ustvariti skupne vojaške organizacije, ki bi ščitila ves osvojeni in kolonizirani prostor, zato so postali podložniki različnim tujim fevdalnim osvajalcem tega prostora (Langobardi, Franki, Germani in drugi) in tudi cerkveni oblasti, ki jih je potem pokristjanila (glej Kos, 1985, ali Grafenauer, 1963). Z načinom prebivanja, posebej pa z obdelavo zemlje, ki ni bila individualna kot pri Rimljanih, ampak kolektivna (glej Fister, 1986, ali Gruden, 1992), so se vrnili daleč v zgodovinsko preteklost tega prostora, to je $\mathrm{v}$ obdobje pred prihodom Rimljanov. Torej grad nad naselbino morda ni bil v lasti domačih fevdalcev, ampak so ga verjetno prevzeli tuji (glej Šenica-Pavletič 2005). Z zgodovinskega vidika je zelo zanimivo vprašanje, ali sta se grad in naselbina formirala sočasno ali ločeno (glej Vilfan, 1956), za to analizo pa je bistveno dejstvo, da sta oba nastala po načelih strateške urbane preventive.

\subsection{Oblikovanje drugega naselbinskega jedra Ljubljane (Novi trg)}

Ko je prvo naselbinsko jedro Stari trg v večstoletnem počasnem procesu svojega razvoja preraslo svoj prostorski, urbani, cerkveni in demografski maksimum, se je začelo prostorsko širiti. Kako počasen in dolg je lahko proces preobrazbe, se še danes vidi v naselju Šiška v sodobni Ljubljani, kjer v centru mesta vse od 13. stoletja naprej še vedno obstajajo kmečka gospodinjstva. Verjetno ni prav nič hitreje potekala verska preobrazba naših prednikov, ki so bili pogani in so slavili gospodarja vesoljstva, ki povzroča grom in blisk (Gruden, 1992). To pomeni, da je prišlo v Starem trgu do strukturalne in verske preobrazbe kmečkega prebivalstva, pri čemer je nastala tudi nova struktura prebivalstva, ki se je začela poleg poljedelstva in ribištva ukvarjati še $s$ trgovanjem in $\mathrm{z}$ obrtništvom (na primer Cevc, 1984; Gestrin, 1984; Simoniti, 1984, in Žontar, 1984). Pričakovali bi, da se bo Stari trg urbanistično širil dalje po desnem bregu Ljubljanice proti Prulam ali v smeri današnjega
Mestnega trga (Tomažič, 1937). Vendar se to ni zgodilo. Stari trg se je v 13. stoletju začel širiti po levem bregu Ljubljanice kot drugo naselbinsko jedro ali Novi trg (glej Kos, 1955), ki se je nahajalo med reko in ostanki emonskega obzidja, to je na obrambno nezaščiteni lokaciji, kar je bilo prav v nasprotju z načeli strateške urbane preventive (slika 8c). Če upoštevamo vse zgodovinske utemeljitve o urbanističnem razvoju Novega trga na novi lokaciji, je bil najverjetnejši razlog za njegov nastanek sorazmeren mir, ki je trajal na tem območju po dolgotrajnih in krvavih vojnah za prevlado med fevdalci v 13. stoletju (glej Valvazor, 1984; ali Simoniti, 1990). Tudi dejstvo, da se je Novi trg razvijal kot trgovska in bolj sproščena urbanistična naselbina, v katero so se naseljevali bogatejši meščani in plemiči, potrjuje mnenje, da je takrat na tem območju vladal mir, zaradi česar v novi naselbini niso bila izpolnjena vsa načela strateške urbane preventive.

\subsection{Oblikovanje tretjega naselbinskega jedra Ljubljane (Mestni trg)}

Namesto da bi se urbani razvoj Ljubljane nadaljeval po levem bregu Ljubljanice, ki je bil ugodnejši za gradnjo, to je v podaljšku (razširitvi) naselbinskega jedra Novi trg, je v 14. stoletju njen razvoj ponovno potekal na desnem bregu Ljubljanice, med reko in Golovcem (glej Kos, 1955). Ta urbanistično nelogična preselitev na desni breg verjetno ni bila naključna, temveč je bila posledica strateške urbane preventive, ki je bila zelo pomembna že pri prvem naselbinskem jedru Stari trg (glej Šumi, 1953). Časovno te preselitve sovpadajo z vojnimi dogodki, ki so vodili k propadu Bizantinskega cesarstva zaradi spopadov $s$ Turki. Ti so se pod poveljstvom sultana Osmana (1288-1326) širili po Mali Aziji (Bleiken, 1976, ali Javornik,1998). Da je bil to pravi čas in da je bila izbira lokacije za tretje naselbinsko jedro z vidika strateške urbane preventive pravilna, potrjujejo tudi poznejši zgodovinski dogodki (slika 8d). Turki so svoje osvajalske pohode na Balkan začeli z zmagami pri polotoku Gallipoli leta 1354 pod vodstvom sultana Oraha (13261359), pri reki Marici leta 1371 in pod sultanom Muratom na Kosovu leta 1389, s katerimi so si dokončno utrli pot v Srednjo Evropo, da bi osvojili Dunaj in Benetke, s tem pa tudi Ljubljano. Do sprememb v načinu obrambe Ljubljane (Stari trg, Novi trg in Mestni trg) je prišlo šele v začetku 15. stoletja, natančneje leta 1415 , ko so se Turki prvič pojavili na tem območju. Leta 1416 je prišlo do prelomnice v širšem pojmovanju narave strateške urbane preventive, to je do utrjevanja mestnih zidov. Ker so se od leta 1469 turški vpadi iz Bosne vrstili kar dvesto let, so takrat z vidika strateške urbane preventive največ pozornosti posvetili izgradnji in utrjevanju mestnega obzidja, o čemer je Kos (1955: 35 in 36) zapisal:

Brez dvoma so v zvezi s prizadevanjem, da se Ljubljana čim bolj zavaruje pred vojnimi nevarnostmi, ki so bile v 15 . in 16 . stoletju 


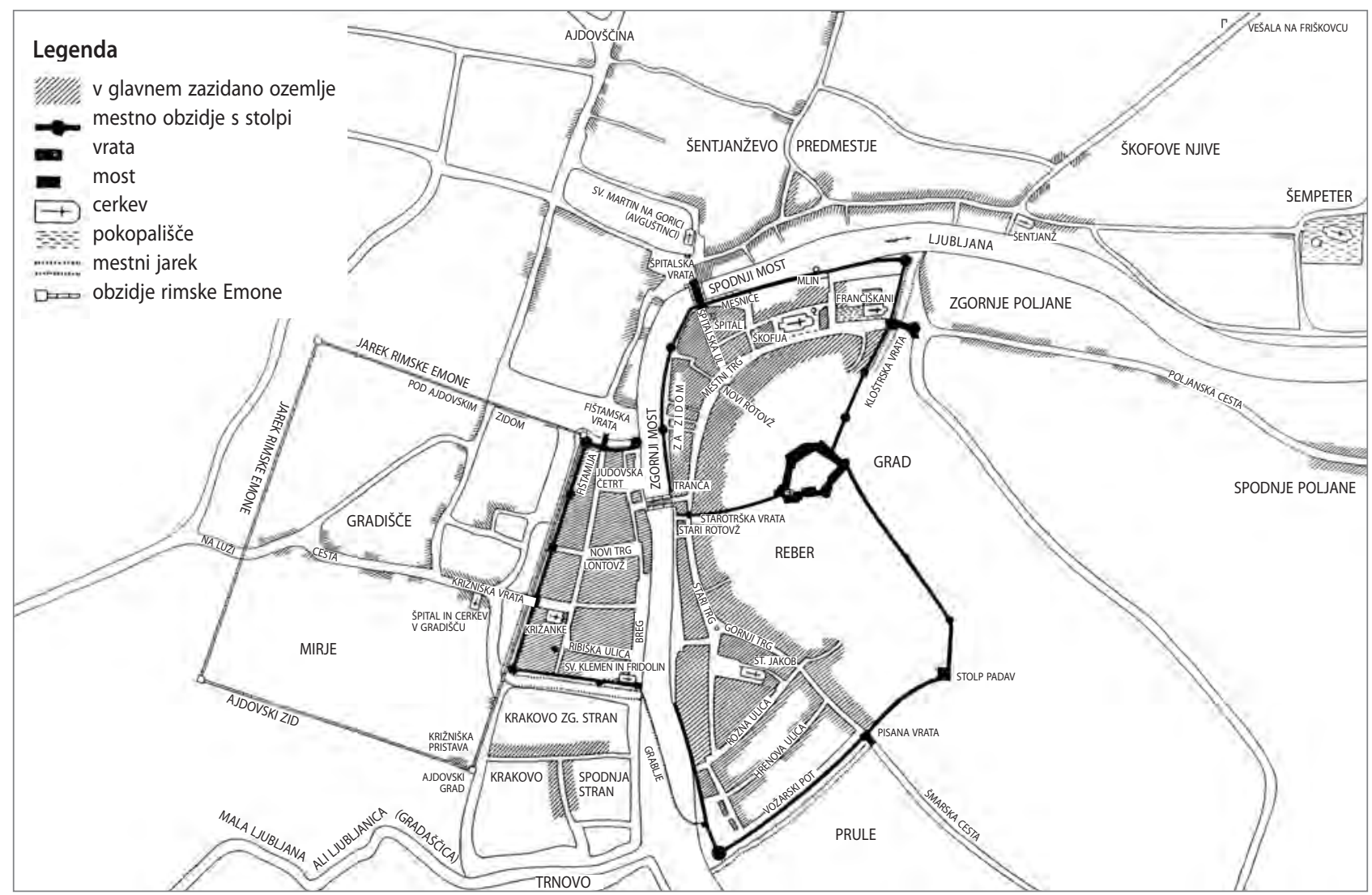

Slika 9: Ljubljana v srednjem veku (Stari trg, Novi trg in Mestni trg; vir: Kos, 1955)

večje kot v prvih stoletjih obstoja ljubljanskega mesta. Vrsta ukrepov je v zvezi s skrbjo pred turško nevarnostjo: 1471, glede rušenja hiš in skednjev v predmestju in pred mestnim obzidjem, pač zato, da ne bi Turki, ko bi se pokazali pred Ljubljano, v njih našli zavetja; iz istih razlogov je bilo odrejeno porušenje samostana in cerkve avguštincev pred Špitalskimi vrati (leta 1494) in porušenje cerkve Matere božje v Gradišču ter cerkve svetega Janeza v predmestju (leta 1554); leta 1499 pa je odrejena zazidava vrat pri komendi križniškega reda.

V medsebojnih fevdalnih vojnah, ki so bile usmerjene $\mathrm{v}$ osvojitev utrjenih fevdalnih gradov in prevzem medsebojnih oblasti, mestno obzidje ni bilo preveč pomembno za zaščito prebivalstva v osvojenih mestih, ker fevdalci praviloma niso pobijali mestnega prebivalstva, zato mesta niso bila povsod utrjena (glej Valvasor, 1984). V vojni s Turki je zgodovina pokazala popolnoma drugačno plat (glej Tomažičc, 1938 ali Simoniti, 1990). Elementi strateške urbane preventive mest so bili zelo pomembni za zaščito prebivalstva, ki bi ga Turki z morebitno osvojitvijo deloma pobili, deloma odpeljali v suženjstvo, mesto pa zažgali in uničili. Vsa tri ljubljanska naselbinska jedra (Stari trg, Novi trg in Mestni trg) je v srednjem veku, ko so se pojavili Turki, obdajalo obzidje (glej Zwitter, 1929-1930). Prav videz tega obzidja potrjuje, da je Ljubljana nastala iz treh naselbinskih jeder, od katerih je bilo vsako posebej utrjena enota (glej Kos, 1955). Ta trojna trdnjava je bila po načelih strateške urbane preventive zavarovana tudi z jarki, prek pobočja Grajskega griča pa je bila povezana še z utrdbami. Ker so prostor naselbin omejevali obrambni zidovi, so na ozkih parcelah nastajale ulice $\mathrm{z}$ večnadstropnimi hišami, stisnjenimi druga k drugi (Šumi, 1953).

\subsection{Vojaški strokovnjaki pri utrjevanju trojnega naselbinskega jedra Ljubljane (Stari trg, Novi trg in Mestni trg)}

Na podlagi danes dostopnih podatkov lahko sklepamo, da je enega najstarejših in najnatančnejših fortifikacijskih načrtov mestnega obzidja Ljubljane $\mathrm{z}$ vidika strateške urbane preventive leta 1586 oblikoval italijanski vojaški arhitekt in graditelj fortifikacij Nicolo Angielini, ki ga je najel dunajski dvor. Angielinijev načrt obstaja v dveh različicah in najbrž dokazuje, da se je mestno obzidje takrat najverjetneje utrjevalo v skladu z njim. $\mathrm{V}$ akvarelno risbo je Angielini natančno vrisal celotno mestno obzidje, pomembnejše zgradbe in preostale predele mesta, vsega drugega, kar se je takrat nahajalo zunaj mestnega obzidja, na primer ljubljanskih predmestij, pa ni vrisal. Čeprav Turki med svojim prvim pohodom, ki je potekal leta 1529 pod sultanom Sulejmanom Veličastnim (1520-1566), niso osvojili Dunaja, to ni pomenilo, da so se zavzetju tega odpovedali, prav nasprotno. Začela se je stoletna vojna med Avstrijo in Turčijo, med katero so Turki okrepili svoje pašaluke na zavzetih ozemljih, 
vključno z Budinom. V strahu, da bodo z zavzetjem južnih pokrajin Turki tudi tu poskušali organizirati nove pašaluke in $s$ tem oslabiti Avstrijo, so kranjski deželni stanovi opozorili cesarja Ferdinanda (1521-1564) na slabo stanje utrdb v južnih slovanskih pokrajinah in zahtevali njihovo okrepitev (glej Mantuani, 1937). Utrdbe niso več zadostovale za obrambo pred Turki, še posebej zaradi spremenjenih strateških okoliščin bojevanja in vojne tehnike, predvsem topništva (slika 9).

Dunajska vlada je na ogled poslala cesarsko vojaško komisijo, to je strokovnjake za strateško urbano preventivo, ki jo je vodil italijanski arhitekt Giovanni Pieroni, takrat znan graditelj fortifikacijskih objektov. Komisija je leta 1638 poleg trdnjave v Karlovcu in drugih utrjenih mest Vojne krajine obiskala tudi Ljubljano. Pieroni je takrat v perorisbi izdelal tloris mesta $s$ trdnjavo na gradu in celotnim obzidjem mesta, vendar ta načrt ni bil nikoli uresničen. Skoraj dvajset let po Pieroniju, leta 1657, so z Dunaja v južne pokrajine ponovno poslali vojaško strokovno komisijo za strateško urbano preventivo, ki jo je vodil cesarski inženir Martin Stier (na primer Mantuani, 1937; Tomažič, 1937, in Voje, 1984). Ta komisija je s štirimi pisnimi poročili, opremljenimi z zemljevidi ter $s$ tlorisi mest in utrdb, cesarja Leopolda (1658-1705) seznanila o ugotovljenem stanju. Za Ljubljano sta najpomembnejši drugo in tretje poročilo, ker vsebujeta talni načrt Ljubljane, podatke o njeni velikosti, utrdbah, trgih, cestah in ulicah ter opis vojaškega stanja mesta (količina topov ter drugega orožja in streliva). V poročilih je bilo navedeno, da je $\mathrm{z}$ vidika strateške urbane preventive v Ljubljani vojaško zavarovan le grad, medtem ko naj bi bil preostali del mesta, ki se je nahajal na desnem in levem bregu Ljubljanice, popolnoma nezavarovan in naj ne bi imel nikakršnih obrambnih možnosti. V svojem predlogu o možnostih strateške urbane preventive Ljubljane, ki bi morala zdržati trimesečno obleganje, je Stier navedel dve stopnji mogoče zaščite. Prva stopnja je obsegala zaščito najbližjih predmestnih naselbin, in sicer od Gradišča na jugu do današnje Tavčarjeve ulice na severu ter od Ljubljanice na vzhodu do današnje Prešernove ulice na zahodu. Utrdbe za zaščito tega območja si je zamislil kot nasipe iz prsti z naperki. Druga stopnja pa je obsegala modernizacijo obstoječih utrdb, in sicer naj bi se na Starem trgu, med vodnimi vrati in Karlovško cesto, zunaj zidovja postavil pomol (bastion) z utrjenim nasipom, ki ga je Stier imenoval »neues werk «. Podobno rešitev je predvideval tudi za prečno utrdbo na Grajskem griču - Planišču. Pri Novem trgu je predlagal, naj se staro zidovje dodatno utrdi z nasipi, na štirih mestih pa naj se v skladu $s$ strateško urbano preventivo zaradi boljše varnosti dogradijo tudi pomoli z bastionom. Okoli utrdbe naj bi se izkopali tudi rovi, v katere naj bi se napeljal potok Gradaščica. Čeprav turški vdori v naše kraje po zadnjem porazu Turkov pred Dunajem leta 1683 niso bili več tako pogosti, je bila leta 1717 na Žabjaku na Novem trgu zgrajena vojašnica za 500 vojakov. Pozneje je postala neprimer- na in leta 1754 so jo predelali v zapor (danes stanovanjska hiša Hrenova ulica 17) (glej Šarac, 2009). Ob koncu 18. stoletja, po dokončni utrditvi Vojne krajine, se je trojno naselbinsko jedro počasi začelo širiti tudi zunaj mestnih zidov. Ker je vzdrževanje obzidij postalo predrago ter ker so zidovi vse bolj ovirali širitev mesta in komunikacijo z njim, je pokrajinska vlada (Kresija) leta 1787 ljubljanski občini ukazala, naj začne rušiti mestne zidove, ki so izgubili svoj obrambni namen (Wester, 1934). Tako je Ljubljana z odpravo trdnjavskega zidovja, ki je stoletja omejevalo njen prostorski in urbanistični razvoj, postala odprto mesto, ki so se mu začela administrativno in urbanistično priključevati ljubljanska predmestja (glej Melik, 1929-1930; ali Mihelič, 1983).

\section{Sklep}

Kot so pokazale zgodovinske študije, se je človek že od svojih prvih naselbin, to je že pri svojih prvih posegih v prostor (prazgodovina), ko je prenehal nagonsko iskati svoja naravna zaklonišča in jih je začel zavestno graditi ter v njih stalno živeti, pričel na različne načine tudi zaščitno ali preventivno varovati. Ni težko ugotoviti, da se je človekova samozaščita v njegovem zgodovinskem razvoju v prostoru vse do današnjega dne izražala na različne načine. Gre pravzaprav za različne dejavnike, s katerimi se je človek želel zavarovati pred vojnami in ki smo jih v tem članku poimenovali strateška urbana preventiva. Ta je bila odvisna predvsem od pogojev, ki jih je nudila narava (lokacija), poleg tega pa tudi od strateške iznajdljivosti in domišlijije posameznikov v urbanem in arhitektonskem smislu ter orožja in ostalih sredstev, ki so se skozi čas in vojne nenehno spreminjala. V zgodovinskem razvoju človeka so vedno obstajali ljudje, ki so imeli prirojeno nadarjenost za vojskovanje (Aleksander Veliki, Atila in drugi) in tudi za kolektivno samozaščito, to je strateško urbano preventivo. Na primeru Ljubljane smo lahko videli, da so se že v srednjem veku usposabljali vojni strokovnjaki arhitektonske in gradbene dejavnosti, to je strokovnjaki za čim boljšo učinkovitost pri uresničevanju strateške urbane preventive. Podobne strokovnjake za strateško urbano preventivo smo še pred kratkim imeli za izgradnjo kolektivnih atomskih zaklonišč. V preseku, ki smo ga naredili skozi zgodovinski, arheološki, geografski, urbani in arhitekturni prostor današnje Ljubljane, smo ugotovili, da se tudi na tem prostoru od prazgodovine do danes nenehno uresničujejo načela strateške urbane preventive. Ker ta niso v zadovoljivi meri obravnavana v obstoječi literaturi o urbanizmu in arhitekturi Ljubljane, je bilo treba pri načrtovani raziskavi vse pomembne ugotovitve, ki se nanašajo na strategijo $\mathrm{v}$ širšem prostoru, analizirati in medsebojno primerjati, nato pa na osnovi novih dognanj sprejeti nove sklepe. Za najpomembnejše vprašanje, ali je prvo naselbinsko jedro Ljubljane (Stari trg) nastalo kot naključna naselbina, je analiza nedvomno pokazala, da je naselbina prav na tej lokaciji nastala kot izvirna 
kmečko-vojaška naselbina in da so na izbiro te lokacije vplivali predvsem vojni razlogi in načela strateške urbane preventive. Tudi tretje naselbinsko jedro Ljubljane (Mestni trg) se je - čeprav v drugačnih zgodovinskih okoliščinah - razvijalo v skladu s pogoji strateške urbane preventive. Čeprav so na levem bregu Ljubljanice obstajali vsi nujni urbanistični pogoji za razvoj mesta, so kot glavni razlog za preselitev na desni breg obveljali boljši varnostni oziroma strateški pogoji, ki jih je zagotavljala narava sama in so se v naslednjih stoletjih izkazali kot upravičeni v vojnah s Turki.

Rezultati raziskave so pomembni, ker so podali jasno in bolj poglobljeno manjkajočo sliko z vojaškega vidika: o nastanku Ljubljane, njeni strateški urbani preventivi, urbanističnem razvoju Stare Ljubljane med dvestoletnim vojaškim obleganjem; zanimivi pa so tudi za nadaljnje raziskave Ljubljane z vojaškega vidika in kot model pri raziskovanju drugih mest pri nas ter, ne nazadnje, kot del kulturne dediščine.

Darko Šarac

Ljubljana, Slovenija

E-pošta: darko.sarac@gmail.com

\section{Zahvala}

Zahvaljujem se mentorici prof. dr. Živi Deu za spodbudo in pravilno usmeritev pri izdelavi članka, dr. Boštjanu Kerblerju za napotke pri sistematizaciji in tehnični pripravi članka ter tudi dr. Nini Novak za lektoriranje članka.

\section{Viri in literatura}

Bergant, T. (1984): Novi rezultati raziskav ljubljanskega barja. V: Gestrin, F. (ur.): Zgodovina Ljubljane. Prispevki za monografijo, str. 23-27. Ljubljana, Zgodovinsko društvo.

Bleiken, J. (1976): Svetovna zgodovina, od začetka do danes. Ljubljana, Cankarjeva založba.

Bogdanov, N., Grlić, D., Iveković, M., Krstić, K., Podhorsky, R., in Vranjican, B. (ur.) (1967): Enciklopedija leksikografskog zavoda, knjiga 2, str. 368-370. Zagreb, Jugoslavenski leksikografski zavod.

Bogdanović, B. (1976): Urbs \& logos: ogledi iz simbologije grada. Niš, Založništvo in izdelava Gradina.

Bratož, R. (1984): Krščanska Emona in njen zaton. V: Gestrin, F. (ur.): Zgodovina Ljubljane. Prispevki za monografijo, str. 64-71. Ljubljana, Zgodovinsko društvo.

Cevc, E. (1984): Likovna umetnost v srednjeveški Ljubljani. V: Gestrin, F. (ur.): Zgodovina Ljubljane. Prispevki za monografijo, str. 96-102. Ljubljana, Zgodovinsko društvo.

Ciglenečki, S. (1992): Polis Norikon. Podsreda, Tiskarna Povše.

Fister, P. (1986): Umetnost stavbarstva na Slovenskem. Ljubljana, Cankarjeva založba.

Gestrin, F. (1984): Ljubljana v 16. in 17. stoletju. V: Gestrin, F. (ur.): Zgodovina Ljubljane. Prispevki za monografijo, str. 105-120. Ljubljana, Zgodovinsko društvo.
Grafenauer, B. (1963): Ljubljana v srednjem veku. Kronika: časopis za slovensko krajevno zgodovino, 11(3), str. 129-139.

Gruden, J. (1992): Zgodovina slovenskega naroda. Celje, Mohorjeva družba.

Javornik, M. (ur.) (1998): Veliki splošni leksikon. Ljubljana. Mladinska knjiga.

Keegan, J. (2005): Zgodovina vojskovanja. Ljubljana, Fakulteta za družbene vede.

Korošec, B. (1991): Ljubljana skozi stoletja: mesto na načrtih, projektih in v stvarnosti. Ljubljana, Mladinska knjiga.

Kos, M. (1955): Srednjeveška Ljubljana. Ljubljana, Tiskarna Toneta Tomšiča.

Kos, M. (1985): Srednjeveška zgodovina Slovencev. Ljubljana, Slovenska matica.

Košir, F. (1993): Zamisel mesta. Ljubljana, Slovenska matica.

Maksimović, B. (1972): Istorija urbanizma. Beograd, Založništvo in izdelava Naučna knjiga.

Mantuani, J. (1937): Najstarejši načrt Ljubljane. Kronika slovenskih mest, 4(3), str. 161-165.

Melik, A. (1929-1930): Razvoj Ljubljane. Geografski vestnik, 5-6, str. 93138.

Mihelič, B. (1983): Urbanistični razvoj Ljubljane. Ljubljana, Znanstveni institut Filozofske fakultete.

Mumford, L. (1969): Mesto v zgodovini. Ljubljana. Državna založba Slovenije.

Plesničar-Gec, L. (1984): Arheološka obdobja Ljubljane. V: Gestrin, F. (ur.): Zgodovina Ljubljane. Prispevki za monografijo, str. 11-20. Ljubljana, Zgodovinsko društvo.

Puš, I. (1984): Ljubljanski prostor v starejši železni dobi. V: Gestrin, F. (ur.): Zgodovina Ljubljane. Prispevki za monografijo, str. 35-45. Ljubljana, Zgodovinsko društvo

Reisp, B. (1998): Gradovi dežele Kranjske. Ljubljana, Slovenska matica.

Simoniti, P. (1984): H kulturnozgodovinski podobi Ljubljane v 16. stoletju. V: Gestrin, F. (ur.): Zgodovina Ljubljane. Prispevki za monografijo, str. 121-124. Ljubljana, Zgodovinsko društvo.

Simoniti, V. (1990): Turki so v deželi že. Celje, Mohorjeva družba.

Sivec, I. (1984): Ljubljana v zgodnjem srednjem veku. V: Gestrin, F. (ur.): Zgodovina Ljubljane. Prispevki za monografijo, str. 69-71. Ljubljana, Zgodovinsko društvo.

Schmid, W. (1941): Emona ni bila vojaški tabor. Glasnik Muzejskega društva za Slovenijo, 22(1-2), str. 44-54.

Slabe, M. (1984): Poskus prikaza poselitve $v$ Ljubljanski kotlini (5. in 6. stoletje ). V: Gestrin, F. (ur.): Zgodovina Ljubljane. Prispevki za monografijo, str. 57-63. Ljubljana, Zgodovinsko društvo.

Stele, F. (1939): Zemljepisni in zgodovinski pogoji srednjeveške Ljubljane. Kronika slovenskih mest, 4(6). str. 49-51.

Šarac, D. (2009): Vojaški kompleksi v Ljubljani in njihova sprememba skozi čas. Magistrsko delo. Ljubljana, Fakulteta za gradbeništvo in geodezijo.

Šarac, D. (2013): Vpliv vojsk na prostorski in urbanistični razvoj mesta Ljubljana [The army's influence on the spatial and urban development of the city of Ljubljana]. Tipkopis.

Šašel, J. (1984): K zgodovini Emone v rimskih napisih in literaturi. V: Gestrin, F. (ur.): Zgodovina Ljubljane. Prispevki za monografijo, str. 28-34. Ljubljana, Zgodovinsko društvo. 
Šenica-Pavletič, V. (2005): Zgodba o Ljubljanskem gradu. Ljubljana, Karantanija.

Šumi, N. (1953): Ob novem predlogu generalnega načrta za Ljubljano. Kronika slovenskih mest, 1(3), str. 201-204.

Tancik, F. (1971): Orožje in bojna oprema od naselitve Slovencev do konca 17. stoletja. Ljubljana, Narodni muzej.

Tomažič, F. (1937): Talni načrt mesta Ljubljana. Kronika slovenskih mest, 4(2), str. 88-103.

Tomažič, F. (1938): Vojna in mesto. Kronika slovenskih mest, 5(2), str. 7893.

Valvasor, J. V. (1984): Slava vojvodine Kranjske. Ljubljana, Mladinska knjiga.

Vilfan, S. (1956): Nekaj vprašanj iz zgodovine Stare Ljubljane. Kronika: časopis za slovensko krajevno zgodovino, 4(3), str. 132-148.

Vilfan, S. (1984): Zgodovina Ljubljane do začetka 16. stoletja. V: Gestrin F. (ur.): Zgodovina Ljubljane. Prispevki za monografijo, str. 75-95. Ljubljana, Zgodovinsko društvo.

Voje, I. (1984): Analiza načrtov Ljubljane iz 16. in 17. stoletja. V: Gestrin, F. (ur.): Zgodovina Ljubljane. Prispevki za monografijo, str. 140-154. Ljubljana, Zgodovinsko društvo.

Wester, J. (1934): Momenti v razvoju Ljubljane od leta 1787 do 1821. Kronika slovenskih mest, 1(1), str. 23-27.

Zwitter, F. (1929-1930): Razvoj ljubljanskega teritorija. Geografski vestnik, 5-6, str. 138-154.

Žontar, J. (1984): Ljubljana v 18. in v prvi polovici 19. stoletja. V: Gestrin, F. (ur.): Zgodovina Ljubljane. Prispevki za monografijo, str. 157-176. Ljubljana, Zgodovinsko društvo. 